\title{
Hajiyev H.B.
}

DOI: $10.25108 / 2304-1730-1749$. iolr.2017.51.70-87

\section{Ineffectiveness of the mechanisms of Council of Europe on resolution of Caucasian conflicts}

\begin{abstract}
Despite the enormous work and contributions of the Council of Europe in protecting and strengthening human rights, that the documents adopted by the Council of Europe, in order to ensure peace and stability in Caucasia, can be considered as an ordinary piece of paper, and the steps taken as ineffective. There are objective and subjective reasons for that. The end of the cold war, existence of political, economic and cultural contradictions between members of the organization, plus the absence of a legal framework on conflict resolution, has led to a decline of its political influence.
\end{abstract}

Key words: Council of Europe; conflicts; resolution; compulsory; mechanisms.

The Council of Europe establishing on the basis of the Chamber dated on May 5, 1949, signed by the Ministers of Foreign Affairs of Denmark, Italy, Ireland, Norway and Sweden, passed long historical path and presently unifies 47 countries.

According to the article 1 of the Chamber, the aim of the Council of Europe is to achieve a greater unity between its members for the purpose of safeguarding and implementation the ideals and principles which are their common heritage and facilitating their economic and social progress. This aim will be pursued through the efforts of organs of the Council by discussion of questions of common concern

- Hajiyev Habib Bahruz oglu - a teacher of Baku State University (Azerbaijan). E-mail: h.hajiyev@hotmail.com 
and by agreements and common action in economic, social, cultural, scientific, legal and administrative matters and in the maintenance and further realization of human rights and fundamental freedoms, through bodies of the European bodies. Issues, regarding the national defense, are not in the competence of the Council of Europe [1].

Even though, the establishment of the unified European space, basing on principles of human rights protection and supremacy, and are the priority line of activity of the Council of Europe, the Organization still pays specific attention to the issues of peaceful resolution of current conflicts and to establishment of peace and security in European space.

Among the countries, of the Caucasian region, Russia became the member of Council of Europe in 1996, Georgia in 1999, Azerbaijan and Armenia in 2001. Council of Europe, with aim of ensuring peace and security, democratization, establishment of civil society, protection of human rights in region, pays strong attention to the conflicts of the region, based on the norms and principles of international law, provides recommendation and give ways to its peaceful resolution. But these recommendations and resolutions remain as a formality, because of the $\mathrm{CE}$ as an organization has no supranational powers and has very reduced arsenal of enforcement mechanisms for their implementation.

Starting from the early 90's of the last century, Nagorno-Karabakh, Abkhazian and South Ossetia conflicts become the object of discussion during the meetings of the Committee of Ministers and Parliamentary Assembly of the Council of Europe. Missions of several levels are sent to the conflict zones, reports are developed. The importance of ensuring the protection of human rights in areas of conflict and their solutions by peaceful means is specially emphasized in resolutions and recommendations.

Council of Europe has provided definite proposals for achievement of the peace and stability in South Caucasus. For example: recommendation no. 1771, 
adopted by PACE in November of 2006, on "Establishment of the Stability Pact in South Caucasus". The idea of organization of the international conference of cooperation and security in South Caucasus for achievement of the stability is stated in this Pact. Moreover, it is recommended to Azerbaijan, Georgia and Armenia to cooperate among themselves [2].

In addition, Parliamentary Assembly of the Council of Europe adopted the decree no. 1416 (2005) "The conflict over Nagorno-Karabakh region dealt with by the OSCE Minsk Conference, a draft of which was prepared by David Atkinson. From legal point of view, this document is of particular importance. The Assembly expresses its concern that the military action, and the widespread ethnic hostilities which preceded it, led to large-scale ethnic expulsion and the creation of mono-ethnic areas which resemble the terrible concept of ethnic cleansing. The Assembly reiterates that the occupation of foreign territory by a member state constitutes a grave violation of that state's obligations as a member of the Council of Europe and reaffirms the right of displaced persons from the area of conflict to return to their homes safely and with dignity [3]. The adoption of this important document which reflects the objective situation of a conflict, it is the result of long and hard work of the Azerbaijani state, and is important for our country. Also, the Assembly, recalling the relevant resolutions of the UN Security Council called upon the parties to implement them, in particular to the withdrawal of the armed forces of Armenia from all occupied territories of the Republic of Azerbaijan. These requirements are also reflected in the recommendation of PACE no. 1690 [4].

If today Azerbaijan has achieved a certain degree of fairness, however, the Council of Europe in adopted first documents on the conflict allowed biased and unfair decisions and did not attempt to devote itself to the true nature of the problem and give proper legal assessment of the situation. 
It should be noted that at the dawn of its independence and in the midst of the Armenian aggression in 1992, our country has officially appealed to the Council of Europe with a request to obtain the status of 'specially invited guest'. But, unfortunately, our appeal for a long time remained without response. This is clearly reflected in the process of solving the Armenian Azerbaijani NagornoKarabakh conflict.

In February 1992, the Committee of the Parliamentary Assembly for relations with the European states of the Council of Europe outside the Council of Europe adopted its first resolution on the Armenian Azerbaijani Nagorno-Karabakh conflict. This resolution expressed concern about the deterioration of the situation in Nagorno-Karabakh, as well as the parties to the conflict were urged to cease fire and resolve the problem through peaceful negotiations. The document also reflected the request for entering the conflict region with Armenia, UN peacekeeping forces.

It should be specially noted that all the early documents, adopted by Committee of the Parliamentary Assembly and the Committee of Ministers, in any way, did not give legal assessment of the Armenian aggression against Azerbaijan, being content merely an expression of concern about the escalation of the conflict. For example, in the decree dated on April of 1993, the Council of Europe Committee of Ministers expressed its support for the UN requirements for the restoration of peace in the region and an advocate of the suspension of military operations. Council of Europe Committee of Ministers showed concern about increased military operations in the Kelbajar district of Azerbaijan, but refused to legally recognize the fact of occupation of the region by Armenian aggressors. Despite the fact that the resolution of the Council of Europe Parliamentary Assembly 1119 (1997) 1 on the conflicts in the Caucasus implies the ability to resolve conflicts only on the basis of the principles of territorial integrity and the award of the autonomous status of Nagorno-Karabakh and Abkhazia in these areas, 
the absence of the Armenian side item aggressor negates all efforts of the organization to resolve the matter.

Therefore, it shall be stressed that though adopted resolutions, continuous of the occupation of Azerbaijani territories by Armenia declines the perspective of adoption of such pacts and resolutions to zero and there is no concrete measure on this direction up to date. Although there is compulsory mechanism of protection of human rights of the Council of Europe, absence of the legal basis for application of these mechanisms namely to these conflicts made serious harm to the role of solution of these conflicts by the organization.

It is well known that the Council of Europe has a strong legal base (European Convention on Human Rights) and coercive mechanisms (the European Commission of Human Rights and the European Court of Human Rights) in protecting the human rights. The value of the Organization's legal framework is not in its fixed rights and freedoms, but in possession of the legal mechanisms for their implementation of it. The French scientist K. Vasak says, "The value of the Convention is determined by the actual mechanism, rather than the rights that it protects" [5]. Unfortunately, the organization does not have similar mechanisms in peace keeping and conflict resolution matters.

Another example of helplessness of the Council of Europe as an organization is its latest attempts to resolve the South Ossetia conflict. In contrast, from the Armenian-Azerbaijani Nagorno-Karabakh conflict, war, between Georgia and Russia on August of 2008, was and is the special subject of discussion of PACE as a result of this particular attention, the resolution no. 1633 was adopted [7].

The obvious matter in this document is that the Parliamentary Assembly especially noted that in the end the peacekeeping format proved that it could not fulfill its intended function and the peacekeepers did not succeed in their mission to protect the life and property of the people in the conflict area. It therefore regrets 
that earlier calls to discuss a change in the format of the peacekeeping and conflict resolution process were rejected by South Ossetia and Russia. Beside, Parliamentary Assembly condemns the recognition by Russia of the independence of South Ossetia and Abkhazia as a violation of international law and Council of Europe statutory principles. The Assembly reaffirms its attachment to the territorial integrity and sovereignty of Georgia and calls on Russia to withdraw its recognition of the independence of South Ossetia and Abkhazia and respects fully the sovereignty and territorial integrity of Georgia, as well as the inviolability of its frontiers and called the parties of the to resolve this problem through negotiations.

Despite all this, the Council of Europe with its limited effective mechanisms is not able to influence the situation, and limits its activity with the adoption of various resolutions (1683 [8] 1647 [9]) at the level of the Parliamentary Assembly, in which expresses its regret that the parties do not fulfill their commitments.

It is worth noting that, unlike the occupied territories of Azerbaijan, the situation in Georgia, is the subject of consolidated report "Conflict in Georgia" of the Secretary General of the Council of Europe. The debate around the 14th consolidated report (November 16, 2016 at the 1271meeting of the Council of Europe Committee of Ministers' Deputies) the member countries of the Organization appreciated the document and supported the continuation of the practice in the future presentation of the consolidated statements.

One of the discussing issues within the frame of the Council of Europe is the situation in Northern Caucasia, especially, in Chechnya. Confrontation between Russia and Chechnya was discussed at Parliamentary Assembly and Ministerial Meetings of the Council of Europe, for several times, reports are developed, dozens of recommendations and resolutions were adopted. Even though, that the Council of Europe states that he acknowledges the territorial integrity of Russian Federation, it was delineated that Russia violates in Chechnya the provisions of 
European Convention of Human Rights, legal provisions of the international humanitarian law and its obligations, undertaken before the Council of Europe.

Council of Europe, in various forms, expresses his annoyance of instable condition in Northern Caucasus in general and not only in Chechnya. In 2006, Parliamentary Assembly made recommendation no. 1751 on "Cultural Diversity of Northern Caucasus". In this document, it is stated that the ethnic and religious situation associated with the identity of the region, and the activity of the states which have interests in this region made the North Caucasus the region of instability. In addition, the absence of genuine traditions of political democracy, high levels of corruption and nepotism, the systematic neglect of the problems of culture and education and the lack of intercultural and interfaith dialogue has led to an increase in inter-ethnic intolerance and violence.

Council of Europe wants the Russian federal and regional authorities to recognize, the importance of culture and education, cultural diversity, intercultural and interreligious dialogue as a possible basis for stability and democratization in medium and long term in the North Caucasus region. The Parliamentary Assembly estimates positively the concretes steps undertaken by Russian authorities nevertheless stating that they are not sufficient. Besides it considers that it is very important to develop trans-border cultural cooperation between Northern Caucasia, and the Republics of Southern Caucasus [10]. Despite these recommendations, the steps taken by Moscow in this direction can hardly be considered as positive.

In conclusion, we can say that the documents adopted by the Council of Europe, in order to ensure peace and stability in Caucasia, can be considered as an ordinary piece of paper, and the steps taken as ineffective. There are objective and subjective reasons for that. The end of the cold war, existence of political, economic and cultural contradictions between members of the organization, plus the absence of a legal framework on conflict resolution, has led to a decline of its political influence. 


\section{References}

1. Statute of the Council of Europe. Available at: https://rm.coe.int/1680306052

2. PACE Recommendation 1771 (2006). The establishment of a stability pact for the South. Available at: http://assembly.coe.int/committee/SC/2006/PER003E.pdf

3. Obsuzhdenie v Assambleye 25 yanvarya 2005 g. Sm.dok. 10364-doklad komissii po politicheskim voprosam (dokldchik g-n Atkinson) [Disscussion in Assambly of 25 January 2005. See report no. 10364. Report of Commission on Political Issues (reporter Mr. Atkinson)] Available at: http://www.coe.int/t/r/parliamentary_assembly/[russian_documents]/[2005]/\%5BJa n2005\%5D/Res1416_rus.asp

4. PACE- Rekomendatsiya Parlamentskoy Assambleyi Soveta Evropy no. 1690, 2015 g. Predvaritel'noe izadnie O konflikte v Nagorno-Karabakhskom regione, resheniem kotorogo zanimaetsya Minskaya Konferentsiya OBSE Rekomendatsiya 1690 (2005) [PACE-Recommendation of Parliamentary Assembly of Council of Europe no. 1690, 2015. Prliminary edition On Conflict in Nagorno-Karabakh region, in resolution of which involved Minsk group of OBSE. Recommendation no. 1690]. Available at: http://www.coe.int/t/r/parliamentary _assembly/[russian_documents]/[2005]/\%5BJan2005\%5D/Rec1690_rus.asp

5. Vasak K. The Council of Europe/The International Dimensions of Human Rights. Paris, 1982, vol. 2.

6. Obsuzhdenie v Assambleye 30 sentyabrya i 2 oktyabrya 2008 g. (30, 34 i 35 zasedaniya). [Discussion in Assembly of 30 September and 2 October 2008 (30, 34 and 35 sessions)]. Available at: http://www.coe.int/t/r/parliamentary_assembly [russian_documents]/\%5B2008\%5D/\%5BNov2008\%5D/Res1633_rus.asp

7. 2 oktaybray 2008 g. Parlamentskaya Assambleya prinyala Rezolutsiyu 1633(2008) o "posledstviyakh voyiny mezgu Gruziyey i Rossiyskoy Federatsiyeyi 
[2 October 2008 Parliamentary Assembly adopted Resolution no. 1633(2008) on consequences of the war between Georgia and Russian Federation]".

8. Council of Europe Parliamentary Assembly. Resolution 1683 (2009). The war between Georgia and Russia: one year after. Available at: http://assembly.coe.int/CommitteeDocs/2010/amondoc29r_2010.pdf

9. Council of Europe Parliamentary Assembly. Resolution 1647 (2009). Implementation of Resolution 1633 (2008) on the consequences of the war between Georgia and Russia. Available at: http://assembly.coe.int/nw/xml/ XRef/Xref-XML2HTML-en.asp?fileid=17681\&lang=en

10. PACE Recommendation 1751 (2006). Cultural diversity of the North Caucasus. Available at: http://assembly.coe.int/Sessions/2006/Standing Com_ Moscou_2006_E.pdf 